\title{
Synthesis and Characterization of Annulene-Fused Pseudorotaxanes
}

Joshua J. Pak, ${ }^{\mathrm{a}, 1}$ Timothy J. R. Weakley, ${ }^{\mathrm{a}}$ Michael M. Haley, ${ }^{\text {*a }}$ Danny Y. K. Lau, ${ }^{\mathrm{b}}$ J. Fraser Stoddart ${ }^{\mathrm{b}}$

a Department of Chemistry, University of Oregon, Eugene, OR 97403-1253 USA

Fax +1(541)3460487; E-mail: haley@oregon.uoregon.edu

b Department of Chemistry, University of California - Los Angeles, 405 Hilgard Avenue, Los Angeles, CA 90095 USA

Fax +1(310)2061843; E-mail: stoddart@chem.ucla.edu

Received 1 April 2002

Abstract: A 24-crown-8 ether-fused dehydrobenzo[18]annulene has been prepared via a stepwise $\mathrm{Pd} / \mathrm{Cu}$-mediated strategy. This annulene-crown ether hybrid forms a pseudorotaxane complex in $\mathrm{CD}_{2} \mathrm{Cl}_{2}$ with dibenzylammonium hexafluorophosphate when they are combined in a 1:1 ratio, as indicated by ${ }^{1} \mathrm{H}$ NMR spectroscopy and mass spectrometry.

Key words: annulenes, crown compounds, macrocycles, pseudorotaxanes, supramolecular chemistry

Phenylacetylene macrocycles ${ }^{2}$ and networks ${ }^{3}$ are potential building blocks for the assembly of tubular and/or porous molecular crystals. ${ }^{4}$ Key to such a transformation is preorganization of the precursor molecules so that they may undergo controlled oligomerization/polymerization to form ordered arrays. Unfortunately, such preorganization in the solid state ${ }^{5}$ is often rare and impossible to predict a priori. For example, tribenzo[14]annulene (1, Figure 1$)^{6}$ packs in the solid state according to the parameters outlined by Enkelmann ${ }^{7}$ for a topochemical diacetylene polymerization. Indeed, 1 readily undergoes 1,4polymerization when heated or exposed to UV light. ${ }^{6}$ Subsequent studies of a number of other dehydrobenzoannulenes (DBAs) show the reactivity displayed by $\mathbf{1}$ to be unique. ${ }^{8}$ More often than not the packing of the macrocycles in the crystal lattice precludes any type of ordered polymerization, which is reflected in the broader $\left(w^{1 / 2} \approx 5-\right.$ $\left.10{ }^{\circ} \mathrm{C}\right)$ than normal $\left(w^{1 / 2}<1{ }^{\circ} \mathrm{C}\right)$ DSC exotherms of the annulenes.

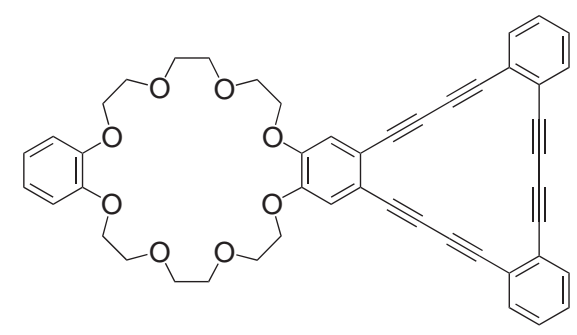

2

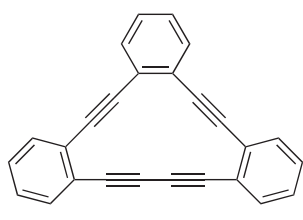

1

Figure 1 The structure of tribenzo[14]annulene (1)

A possible solution to the preorganization problem involves supramolecular chemistry. ${ }^{9}$ Over the last decade a tremendous number of ordered arrays and assemblies have been prepared utilizing various noncovalent bonding interactions (hydrogen bonding, $\pi$-stacking, dipole-dipole interactions, etc.). ${ }^{10}$ One of the more interesting and relevant examples was the recent use of supramolecular organization for the first 1,6-polymerization of a triacetylene. ${ }^{11}$ Similar preorganization has been successfully used for the polymerization of a number of other diacetylenes. ${ }^{12}$ Encouraged by these reports, we decided to target a new class of pseudorotaxanes using crown etherdehydrobenzoannulene hybrids (e.g, 2) in order to organize the DBA molecules. These systems can utilize external forces such as the interpenetrating guest-host interaction between secondary dialkylammonium ion centers in guests containing one or more binding sites for crown ether hosts. ${ }^{13}$ The resultant supramolecular complexes might thermally generate dimer fragments, which could provide insight into diacetylene polymerization for DBA systems. We describe herein our initial work to-

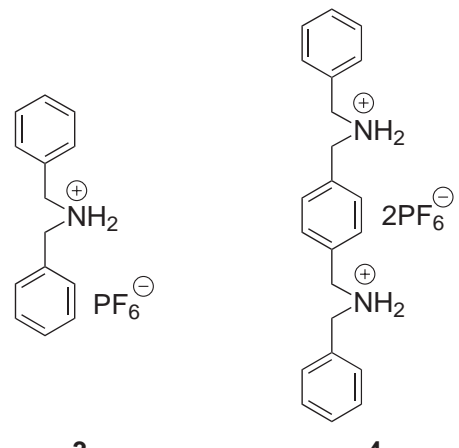

3

Figure 2 The structures of crown ether-dehydrobenzoannulene hybrid $\mathbf{2}$ and mono- and dicationic hexafluorophosphate salts $\mathbf{3}$ and $\mathbf{4}$

Synthesis 2002, No. 9, 0107 2002. Article Identifier:

1437-210X,E;2002,0,09,1256,1260,ftx,en;C11602SS.pdf.

(c) Georg Thieme Verlag Stuttgart · New York

ISSN 0039-7881 
wards the assembly of novel supramolecular architectures containing hybrid $\mathbf{2}$ and the mono- and dicationic hexafluorophosphate salts $\mathbf{3}$ and $\mathbf{4}$, respectively (Figure 2).

Hybrid 2 was assembled using the same strategy as that reported previously for the construction of site-specifically functionalized DBAs (Scheme 1). ${ }^{8 \mathrm{~b}, \mathrm{f}, \mathrm{g}}$ Cyclization of ditosylate $\mathbf{5}^{14}$ with 4,5 -diiodocatechol ${ }^{15}$ using high dilution conditions gave diiododibenzo-24-crown-8 (6) in moderate yield. Cross-coupling $\mathbf{6}$ with two equivalents of 1-(4-trimethylsilylbuta-1,3-diynyl)-2-(triisopropylsilylethynyl)benzene ${ }^{8 \mathrm{~g}}$ using in situ desilylation/coupling conditions furnished the $\alpha, \omega$-polyyne 7 in $81 \%$ yield. Desilylation of 7 with $\mathrm{Bu}_{4} \mathrm{NF}$ and subsequent $\mathrm{Cu}$-mediated intramolecular oxidative cyclization under pseudohigh dilution conditions generated the benzo-24-crown-8fused annulene 2 as a light yellow solid in $55 \%$ yield.
Slow evaporation of a THF solution of $\mathbf{2}$ afforded yellow blocks suitable for X-ray diffraction. The crystal structure of macrocycle 2 is shown in Figure $3 .{ }^{16}$ The annulenic core is essentially planar with a mean deviation less than $0.07 \AA$. The bond lengths and bond angles are typical for those found in other dehydrobenzoannulenes. ${ }^{6,8}$ Interestingly, the crown ether curves around the end of a second annulene. Although there are no $\pi$-stacking interactions in the crystal lattice, there are short $\mathrm{CH}$...O hydrogen bonds that help dictate the crystal packing. With such a curved arrangement, it might be possible to thread both the crown ether and annulene, a motif we are actively pursuing.

Mixing equimolar amounts of hybrid $\mathbf{2}$ and salt $\mathbf{3}$ in $\mathrm{CD}_{2} \mathrm{Cl}_{2}$ at room temperature resulted in a significant difference in the ${ }^{1} \mathrm{H}$ NMR spectra (Figure 4), thus indicating formation of the pseudorotaxane host-guest complex. The top spectrum, which represents free $\mathbf{2}$, is relatively uncomplicated, reflecting the $\mathrm{C}_{2 \mathrm{v}}$ symmetry of the crown

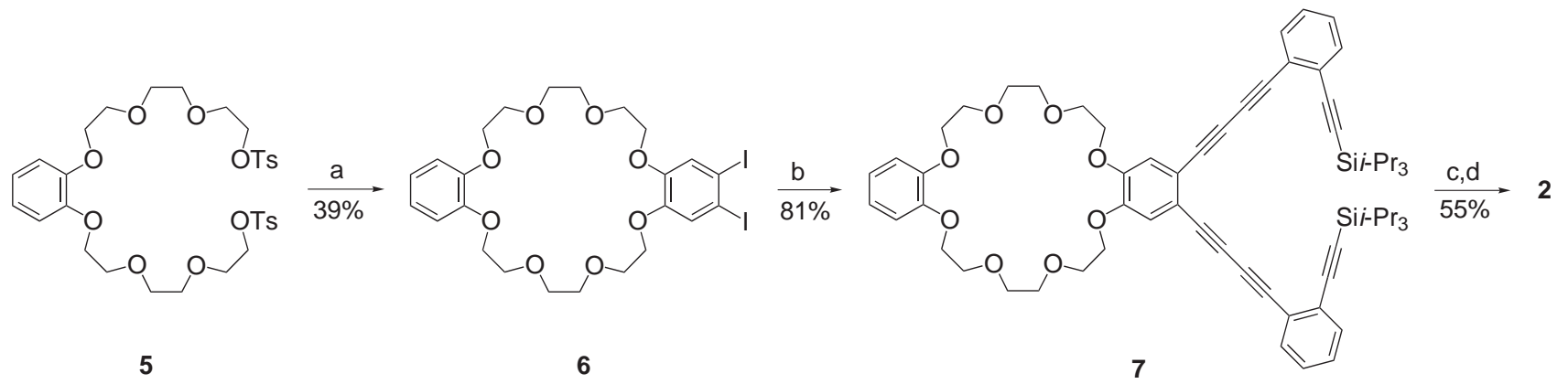

Scheme 1 (a) 4,5-diiodocatechol, $\mathrm{CsCO}_{3}, \mathrm{MeCN}$; (b) 1-(4-trimethylsilylbuta-1,3-diynyl)-2-(triisopropylsilylethynyl)benzene, aq $\mathrm{KOH}$, $\mathrm{PdCl}_{2}\left(\mathrm{PPh}_{3}\right)_{2}, \mathrm{CuI}, \mathrm{Et}_{3} \mathrm{~N}, \mathrm{THF}$; (c) $\mathrm{Bu}_{4} \mathrm{NF}, \mathrm{MeOH}, \mathrm{THF} ;(\mathrm{d}) \mathrm{Cu}(\mathrm{OAc})_{2}, \mathrm{CuCl}$, pyridine
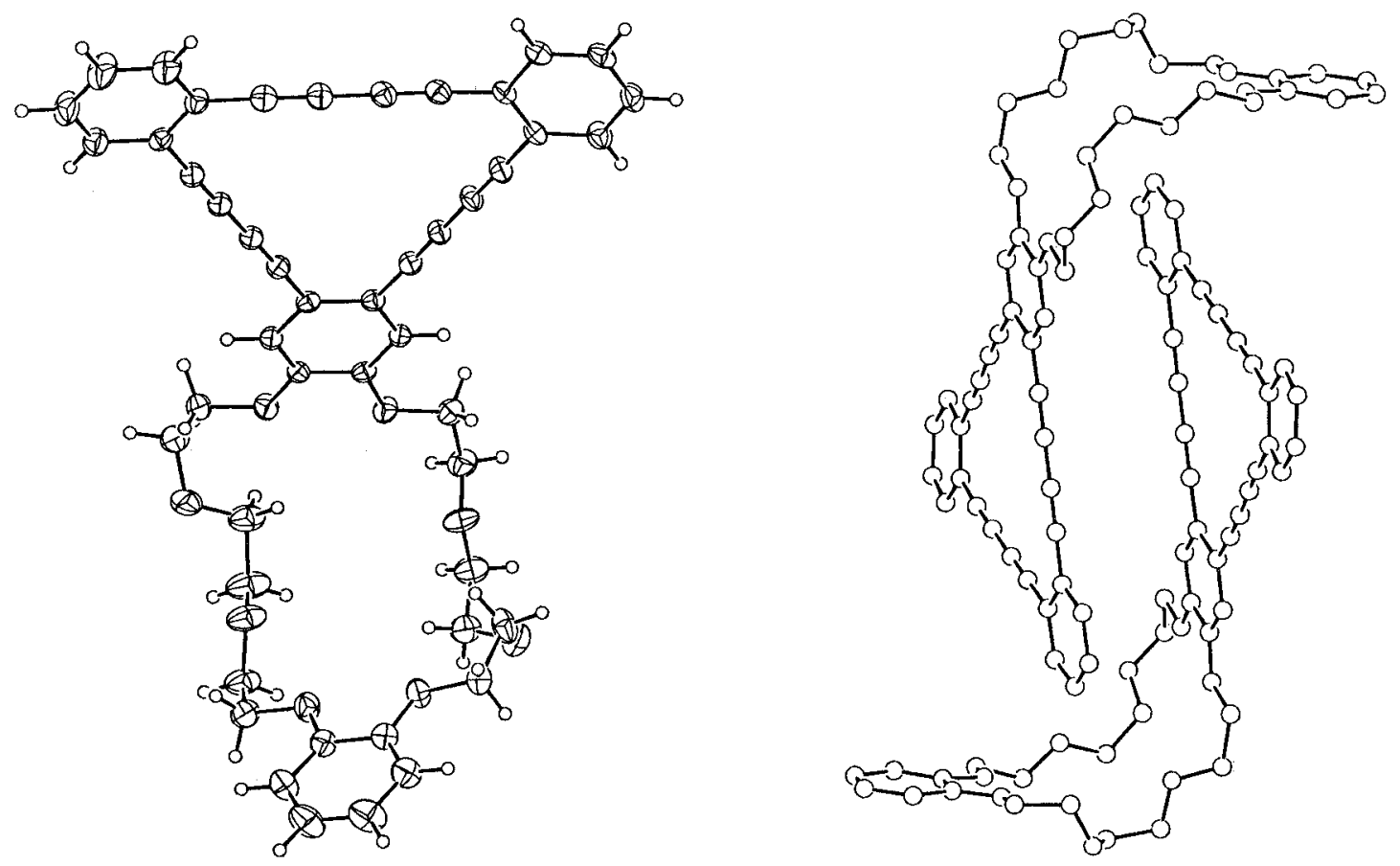

Figure 3 Molecular structure of 2 (left); ellipsoids drawn at the $30 \%$ level. Side view of two molecules (right). THF solvate molecules omitted for clarity 

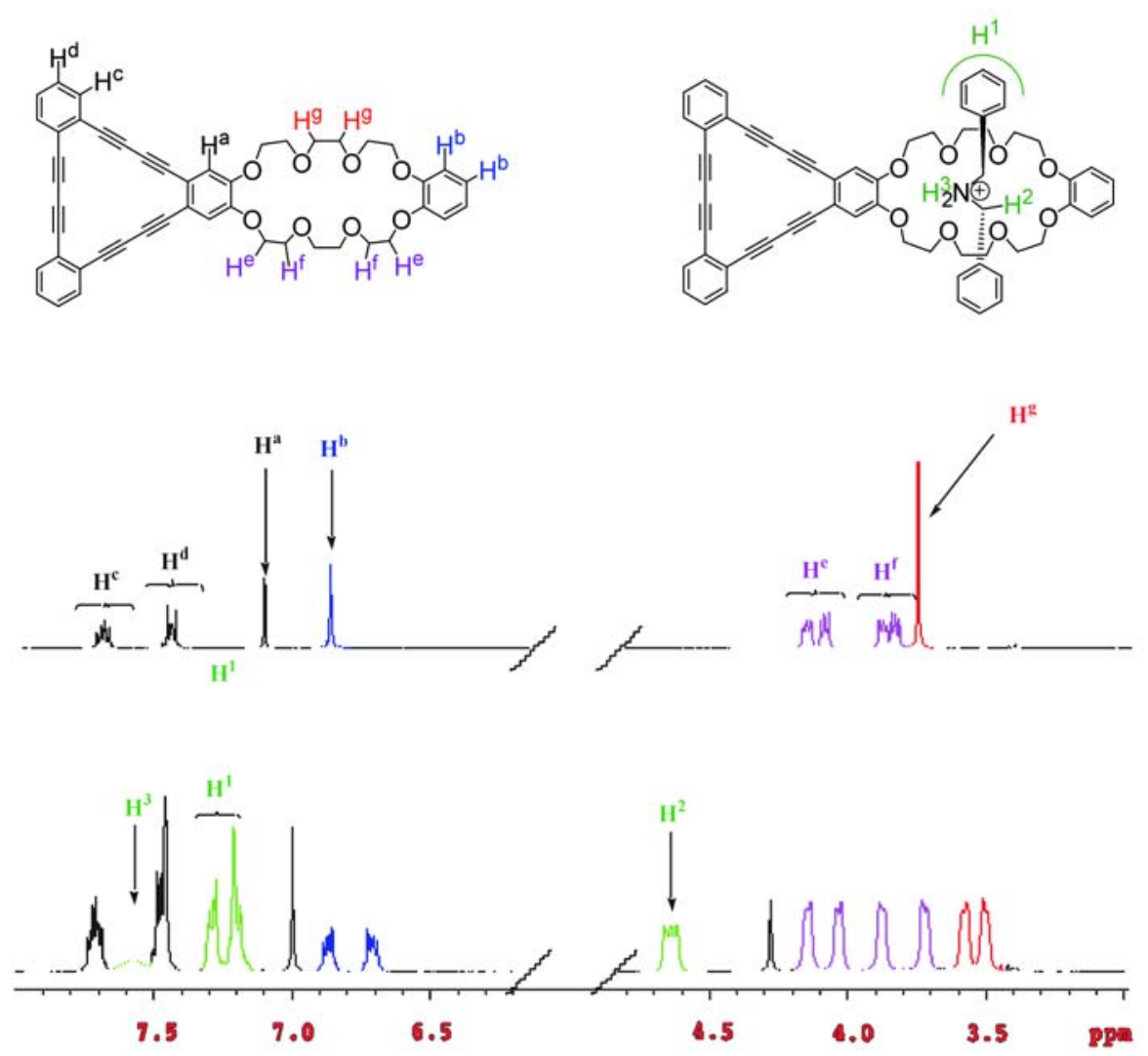

Figure $4{ }^{1} \mathrm{H}$ NMR $\left(300 \mathrm{MHz}, \mathrm{CD}_{2} \mathrm{Cl}_{2}\right.$ ) spectra of the free hybrid 2 (top) and of the 1:1 pseudorotaxane $\mathbf{2 \cdot 3}$ (bottom)

ether moiety. The bottom spectrum shows a number of changes upon addition of an equimolar amount of $\mathbf{3}$, all of which support strong complexation. The most noticeable differences are in the crown ether region, where the central ethylene protons $\left(\mathrm{H}^{\mathrm{g}}\right)$ change from a singlet in free $\mathbf{2}$ to two multiplets in pseudorotaxane $\mathbf{2 \cdot 3}$ (Figure 5) with an upfield shift of ca. $0.25 \mathrm{ppm}$. Crown ether protons $\mathrm{H}^{\mathrm{e}}$ and $\mathrm{H}^{\mathrm{f}}$ show increased separations between the two sets of multiplets as well as slight upfield shifts. The resonances in the aromatic region also exhibit notable changes. The broad singlet attributable to the four $\mathrm{H}^{\mathrm{b}}$ protons in $\mathbf{2}$ splits into the expected $\mathrm{AA}^{\prime} \mathrm{BB}^{\prime}$ multiplet with an upfield shift of ca. $0.1 \mathrm{ppm}$ once the complex is formed. The singlet for
$\mathrm{H}^{\mathrm{a}}$ shifts upfield by $0.15 \mathrm{ppm}$. Resonances of the ammonium ion were observed at $\delta=7.57$ (broad singlet), 7.327.13 (multiplets), and 4.74 (broad triplet) representing $\mathrm{H}^{3}$, $\mathrm{H}^{1}$, and $\mathrm{H}^{2}$, respectively. Based on the large number of previous pseudorotaxane studies, ${ }^{13}$ the observed chemical shift changes, as well as there being no indication of free 2, are consistent with strong complexation between the host and guest molecules.

The supramolecular complex $\mathbf{2 \cdot 3}$ was also analyzed by FAB mass spectrometry. Although the spectrum did not show the parent peak of $\mathrm{m} / \mathrm{z} 1085$, peaks corresponding to $\mathrm{M}^{+}-\mathrm{PF}_{6}$ and hybrid 2 were observed at 940 and 742 mass

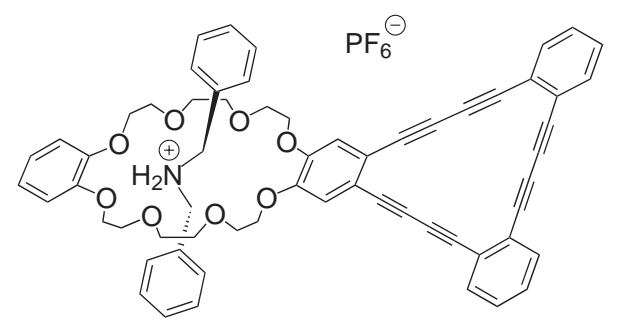

$2 \cdot 3$

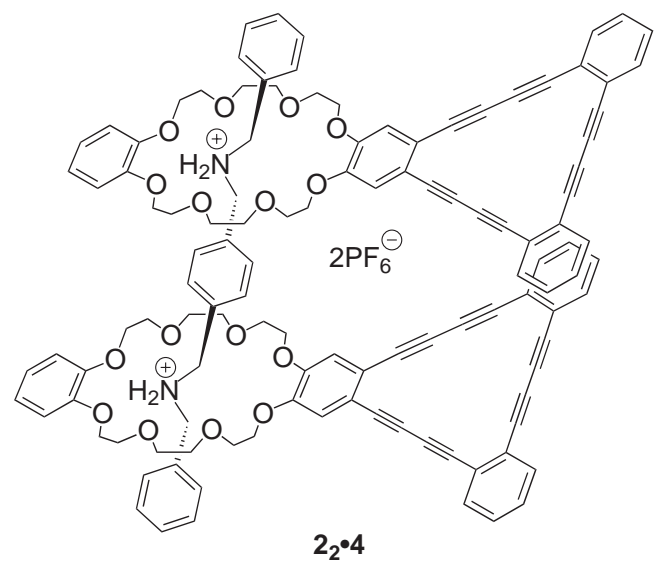

Figure 5 The structures of 1:1 pseudorotaxane $\mathbf{2} \cdot \mathbf{3}$ and 2:1 pseudorotaxane $\mathbf{2}_{\mathbf{2}} \cdot \mathbf{4}$ 
units, respectively. Attempts to obtain single crystals suitable for X-ray diffraction have been unsuccessful to date.

The complexation between DBA 2 and the bis-ammonium salt 4 was also performed in $\mathrm{CD}_{2} \mathrm{Cl}_{2}$ by mixing a $2: 1$ ratio of host and thread molecules (Figure 5). The results of this experiment are considerably more complicated. ${ }^{1} \mathrm{H}$ NMR spectra indicated the presence of a mixture of pseudorotaxane complexes and their free components in solution. The FAB mass spectrum showed very small peaks of the 2:1 complex corresponding to $\mathrm{M}^{+}-\mathrm{PF}_{6}, \mathrm{M}^{+}-2 \mathrm{PF}_{6}$, and crown ether 2 containing a sodium ion. Further efforts to decipher these results are in progress.

In conclusion, we have demonstrated an efficient synthesis of crown ether containing dehydrobenzoannulene $\mathbf{2}$ and its ability to complex secondary dialkylammonium ions. The formation of a pseudorotaxane from a 1:1 mixture of 2 and 3 is facile in $\mathrm{CD}_{2} \mathrm{Cl}_{2}$, according to ${ }^{1} \mathrm{H} \mathrm{NMR}$ spectroscopic data. The formation of the corresponding [3]pseudorotaxane from a 2:1 mixture of $\mathbf{2}$ and $\mathbf{4}$ was incomplete under analogous conditions. Synthetic efforts towards making bis- and tris-crown ether-fused annulenes are underway and experiments to probe the formation of more complicated supermolecules will be reported in due course.

Reagents and instrumentation used have been described previously. ${ }^{8 g}$

\section{4,5-Diiododibenzo-24-crown-8 (6)}

A suspension of $\mathrm{CsCO}_{3}(18.4 \mathrm{~g}, 56.5 \mathrm{mmol})$ in anhyd $\mathrm{MeCN}(250$ $\mathrm{mL}$ ) was placed under $\mathrm{N}_{2}$ and brought to reflux. To this was added ditosylate $\mathbf{5}^{14}(7.72 \mathrm{~g}, 11.3 \mathrm{mmol})$ and 4,5-diiodocatechol ${ }^{15}(4.09 \mathrm{~g}$, $11.3 \mathrm{mmol})$ dissolved in anhyd $\mathrm{MeCN}(250 \mathrm{~mL})$ over a $24 \mathrm{~h}$ period. The mixture was refluxed for an additional $48 \mathrm{~h}$ and then cooled. The suspension was filtered and concentrated in vacuo. The residue was dissolved in $\mathrm{CH}_{2} \mathrm{Cl}_{2}(150 \mathrm{~mL})$ and washed with aq sat. $\mathrm{NaHCO}_{3}$ solution $(150 \mathrm{~mL})$. The aqueous layer was extracted with $\mathrm{CH}_{2} \mathrm{Cl}_{2}(2 \times 100 \mathrm{~mL})$ and the combined organics were dried $\left(\mathrm{MgSO}_{4}\right)$, filtered, and concentrated. Chromatography on silica gel (hexanes-EtOAc, 1:1) gave $6(3.09 \mathrm{~g}, 39 \%)$ as a white solid; mp 91.7-93.6 ${ }^{\circ} \mathrm{C}$.

IR $\left(\mathrm{CDCl}_{3}\right): 3062,2922,2870,1592,1249,1127 \mathrm{~cm}^{-1}$.

${ }^{1} \mathrm{H} \mathrm{NMR}\left(\mathrm{CDCl}_{3}\right): \delta=7.24(\mathrm{~s}, 2 \mathrm{H}), 6.92-6.84(\mathrm{~m}, 4 \mathrm{H}), 4.16-4.12$ (m, 4 H), 4.10-4.06 (m, 4 H), 3.93-3.86 (m, 8 H), 3.84-3.77 (m, 8 $\mathrm{H})$.

${ }^{13} \mathrm{C}$ NMR $\left(\mathrm{CDCl}_{3}\right): \delta=149.44,148.85,123.89,121.39,113.97$, 96.47, 71.35, 71.23, 69.91, 69.64, 69.56, 69.32.

MS (APCI): $m / z(\%)=718\left(100, \mathrm{M}^{+}+\mathrm{H}_{2} \mathrm{O}\right), 701\left(5, \mathrm{M}^{+}+\mathrm{H}\right)$.

Anal. Calcd for $\mathrm{C}_{24} \mathrm{H}_{30} \mathrm{I}_{2} \mathrm{O}_{8}$ (700.30): C, 41.16; H, 4.32. Found: C, 40.98; H, 4.23.

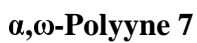

The diiodide 6 (981 mg, $1.4 \mathrm{mmol}$ ) and 1-(4-trimethylsilylbuta-1,3diynyl)-2-(triisopropylsilylethynyl)benzene ${ }^{8 \mathrm{~g}}(1.59 \mathrm{~g}, 4.2 \mathrm{mmol})$ were dissolved in $\mathrm{H}_{2} \mathrm{O}-\mathrm{THF}-\mathrm{Et}_{3} \mathrm{~N}(0.01: 1: 5,20 \mathrm{~mL})$ in separate vessels. The solutions were degassed vigorously by three freezepump-thaw cycles. The acetylene solution was added via syringe pump to the solution of $\mathbf{6}$ charged with $\mathrm{PdCl}_{2}\left(\mathrm{PPh}_{3}\right)_{2}(35 \mathrm{mg}, 0.05$ $\mathrm{mmol}), \mathrm{CuI}(15 \mathrm{mg}, 0.08 \mathrm{mmol})$, and $\mathrm{KOH}$ (2.36 g, $42 \mathrm{mmol})$ over $12 \mathrm{~h}$ at $50{ }^{\circ} \mathrm{C}$ under $\mathrm{N}_{2}$. Upon completion, the mixture was concen- trated in vacuo and redissolved in $\mathrm{CH}_{2} \mathrm{Cl}_{2}$. The dark residue was filtered through a thin cake of silica gel using $\mathrm{CH}_{2} \mathrm{Cl}_{2}$ and concentrated. Chromatography on silica gel (hexanes-THF, 3:1) gave polyyne $7(1.21 \mathrm{~g}, 81 \%)$ as a tan gum.

IR (neat): 2946, 2866, 2415, $2203 \mathrm{~cm}^{-1}$.

${ }^{1} \mathrm{H} \mathrm{NMR}\left(\mathrm{CDCl}_{3}\right): \delta=7.54-7.45(\mathrm{~m}, 4 \mathrm{H}), 7.33-7.21(\mathrm{~m}, 4 \mathrm{H}), 6.92$ (s, $2 \mathrm{H}), 6.89$ (br s, $4 \mathrm{H}), 4.19-4.11(\mathrm{~m}, 8 \mathrm{H}), 3.96-3.91(\mathrm{~m}, 8 \mathrm{H})$, 3.84 (br s, $8 \mathrm{H}), 1.16$ (s, $42 \mathrm{H})$.

${ }^{13} \mathrm{C} \mathrm{NMR}\left(\mathrm{CDCl}_{3}\right): \delta=149.39,148.84,132.66,132.28,128.53$, $127.86,127.18,124.91,121.37,118.56,116.85,113.91,104.56$, $96.06,81.31,80.55,78.06,77.11,71.47,71.29,69.94,69.52,69.43$, 69.36, 18.70, 11.30.

HRMS: $m / z$ Calcd for $\mathrm{C}_{66} \mathrm{H}_{80} \mathrm{O}_{8} \mathrm{Si}_{2}\left(\mathrm{M}^{+}\right)$: 1056.5392. Found: 1056.5386.

\section{Crown Ether/Annulene Hybrid 2}

Polyyne 7 (850 mg, $0.78 \mathrm{mmol}$ ) was dissolved in THF-MeOH (3:1, $20 \mathrm{~mL})$ and treated with $\mathrm{Bu}_{4} \mathrm{NF}(2 \mathrm{~mL}, 1 \mathrm{M}$ THF solution, 2.0 $\mathrm{mmol})$ at r.t. The reaction was monitored by TLC and was complete within $30 \mathrm{~min}$. The mixture was diluted with $\mathrm{Et}_{2} \mathrm{O}(30 \mathrm{~mL})$, washed with $\mathrm{H}_{2} \mathrm{O}(3 \times 20 \mathrm{~mL})$ and brine $(2 \times 20 \mathrm{~mL})$, and then dried $\left(\mathrm{MgSO}_{4}\right)$. The organic layer was concentrated in vacuo and the resultant oil was redissolved in pyridine $(10 \mathrm{~mL})$. The pyridine solution was added over $12 \mathrm{~h}$ via syringe pump to a flask charged with $\mathrm{Cu}(\mathrm{OAc})_{2}(3.54 \mathrm{~g}, 19.5 \mathrm{mmol}), \mathrm{CuCl}(2.10 \mathrm{~g}, 15.6 \mathrm{mmol})$, and pyridine $(200 \mathrm{~mL})$ at $60{ }^{\circ} \mathrm{C}$. The addition was done under house air and stirred further for $8 \mathrm{~h}$. Upon completion, the mixture was concentrated in vacuo and then redissolved in $\mathrm{CH}_{2} \mathrm{Cl}_{2}$. The mixture was filtered through a thin cake of silica gel using $\mathrm{CH}_{2} \mathrm{Cl}_{2}$ and concentrated. Chromatography on silica gel (hexanes-THF, 3:1) afforded 2 (320 mg, 55\%) as a light yellow solid; $\mathrm{mp} 230^{\circ} \mathrm{C}$ (dec.).

IR (KBr): 2926, 2866, 2211, 2192, $2140 \mathrm{~cm}^{-1}$.

${ }^{1} \mathrm{H}$ NMR $\left(\mathrm{CD}_{2} \mathrm{Cl}_{2}\right): \delta=7.74-7.66(\mathrm{~m}, 4 \mathrm{H}), 7.49-7.42(\mathrm{~m}, 4 \mathrm{H})$, 7.13 (s, 2 H), 6.89 (br s, 4 H), 4.19-4.15 (m, 4 H), 4.12-4.08 (m, 4 $\mathrm{H}), 3.92-3.82(\mathrm{~m}, 8 \mathrm{H}), 3.77$ (br s, $8 \mathrm{H})$.

${ }^{13} \mathrm{C}$ NMR $\left(\mathrm{CD}_{2} \mathrm{Cl}_{2}\right): \delta=150.47,129.54,133.35,133.15,129.61$, $129.40,125.63,125.29,121.89,118.97,116.84,114.69,81.76$, $81.32,80.96,78.49,78.16,77.00,71.83,71.63,70.41,70.00,69.97$, 69.76 .

MS (FAB): $m / z=742.2\left(100, \mathrm{M}^{+}\right)$.

Anal. Calcd for $\mathrm{C}_{48} \mathrm{H}_{38} \mathrm{O}_{8} \cdot \mathrm{C}_{4} \mathrm{H}_{8} \mathrm{O}$ (814.93): C, 76.64; H, 5.69. Found: C 76.54, H 5.65.

\section{Pseudorotaxane $\mathbf{2 \cdot 3}$}

$\mathrm{CD}_{2} \mathrm{Cl}_{2}(0.7 \mathrm{~mL})$ was added to hybrid $2(11 \mathrm{mg}, 0.015 \mathrm{mmol})$ and dibenzylammonium hexafluorophosphate $(4.8 \mathrm{mg}, 0.014 \mathrm{mmol})$. The reaction mixture was sonicated for $3 \mathrm{~min}$ and then filtered through a plug of glass wool into an NMR tube.

${ }^{1} \mathrm{H}$ NMR $\left(\mathrm{CD}_{2} \mathrm{Cl}_{2}\right): \delta=7.76-7.69(\mathrm{~m}, 4 \mathrm{H}), 7.58(\mathrm{br} \mathrm{s}, 2 \mathrm{H}), 7.50$ $7.44(\mathrm{~m}, 4 \mathrm{H}), 7.36-7.27(\mathrm{~m}, 4 \mathrm{H}), 7.25-7.17$ (m, $6 \mathrm{H}), 6.88$ (BB'm, $2 \mathrm{H}), 6.72$ (AA'm, $2 \mathrm{H}), 4.68-4.62(\mathrm{~m}, 2 \mathrm{H}), 4.16-4.13(\mathrm{~m}, 2 \mathrm{H})$, 4.05-4.02 (m, 2 H), 3.89-3.86 (m, 2 H), 3.74-3.71 (m, 2 H), 3.60$3.55(\mathrm{~m}, 2 \mathrm{H}), 3.53-3.49(\mathrm{~m}, 2 \mathrm{H})$.

MS (FAB): $m / z=940.3\left(82, \mathrm{M}^{+}-\mathrm{PF}_{6}\right), 742.2\left(13, \mathrm{M}^{+}-\mathrm{Bz}_{2} \mathrm{NH}_{2} \mathrm{PF}_{6}\right)$.

\section{Acknowledgements}

We thank the National Science Foundation (CHE-0104854 to M.M.H. and CHE-9910199 to J.F.S.) for support of this research. J.J.P. acknowledges the ACS Division of Organic Chemistry for a DOC Graduate Fellowship (1998-1999). We thank A. J. Boydston for his help with the acquisition of some characterization data. 


\section{References}

(1) Current address: Department of Chemistry, Idaho State University, Pocatello, ID 83209, USA.

(2) Haley, M. M.; Pak, J. J.; Brand, S. C. Top. Curr. Chem. 1999, 201, 81.

(3) Haley, M. M.; Wan, W. B. In Advances in Strained and Interesting Organic Molecules, Vol. 8; Halton, B., Ed.; JAI Press: New York, 2000, 1-41.

(4) Inter alia: (a) Baughman, R. H.; Galvao, D. S. Nature 1993, 365, 635. (b) He, C. B.; Liu, P. W.; Griffin, A. C. Macromolecules 1998, 31, 3145. (c) Grima, J. N.; Evans, K. E. Chem. Commun. 2000, 1531.

(5) For relevant acetylene-containing examples, inter alia: (a) Gardner, G. B.; Venkataraman, D.; Moore, J. S.; Lee, S. Nature 1995, 374, 792. (b) Coates, G. W.; Dunn, A. R.; Henling, L. M.; Dougherty, D. A.; Grubbs, R. H. Angew. Chem., Int. Ed. Engl. 1997, 36, 248. (c) Kiang, Y.-H.; Gardner, G. B.; Lee, S.; Xu, Z.; Lobkovsky, E. B. J. Am. Chem. Soc. 1999, 121, 8204. (d) Kolotuchin, S. V.; Thiessen, P. A.; Fenlon, E. E.; Wilson, S. R.; Loweth, C. J.; Zimmerman, S. C. Chem.-Eur. J. 1999, 5, 2537. (e) Kiang, Y.-H.; Gardner, G. B.; Lee, S.; Xu, Z. J. Am. Chem. Soc. 2000, 122, 6871. (f) Xu, Z.; Lee, S.; Kiang, Y.-H.; Mallik, A. B.; Tsomaia, N.; Mueller, K. T. Adv. Mater. 2001, 13, 637. (g) See also Refs. ${ }^{11,12}$

(6) Baldwin, K. P.; Matzger, A. J.; Scheiman, D. A.; Tessier, C. A.; Vollhardt, K. P. C.; Youngs, W. J. Synlett 1995, 1215.

(7) Enkelmann, V. Adv. Polym. Sci. 1984, 63, 91.

(8) (a) Boese, R.; Matzger, A. J.; Vollhardt, K. P. C. J. Am. Chem. Soc. 1997, 119, 2052. (b) Haley, M. M.; Bell, M. L.; English, J. J.; Johnson, C. A.; Weakley, T. J. R. J. Am. Chem. Soc. 1997, 119, 2956. (c) Tovar, J. D.; Jux, N.; Jarrosson, T.; Khan, S. I.; Rubin, Y. J. Org. Chem. 1997, 62, 3432. (d) Correction: Tovar, J. D.; Jux, N.; Jarroson, T.; Khan, S. I.; Rubin, Y. J. Org. Chem. 1998, 63, 4856. (e) Bunz, U. H. F.; Enkelmann, V. Chem.-Eur. J. 1999, 5, 263. (f) Pak, J. J.; Weakley, T. J. R.; Haley, M. M. J. Am. Chem. Soc. 1999, 121, 8182. (g) Bell, M. L.; Chiechi, R. C.; Johnson, C. A.; Kimball, D. B.; Matzger, A. J.; Wan, W. B.; Weakley, T. J. R.; Haley, M. M. Tetrahedron 2001, 57, 3507.

(9) (a) Fyfe, M. C. T.; Stoddart, J. F. Acc. Chem. Res. 1997, 30, 393. (b) Lehn, J.-M. Supramolecular Chemistry; VCH: Weinheim, 1995. (c) Comprehensive Supramolecular Chemistry; Atwood, J. L.; Davies, J. E. D.; MacNicol, D. D.; Vögtle, F., Eds.; Pergamon: Oxford, 1996. (d) Schneider, H.-J.; Yatsimirsky, A. Principles and Methods in Supramolecular Chemistry; Wiley: Chichester, 2000. (e) Desiraju, G. R. Nature 2001, 412, 397.

(10) Inter alia: (a) Lindsey, J. S. New J. Chem. 1991, 153. (b) Philp, D.; Stoddart, J. F. Synlett 1991, 445. (c) Whitesides, G. M.; Mathias, J. P.; Seto, C. T. Science 1991, 154, 1312. (d) Lawrence, D. S.; Jiang, T.; Levett, M. Chem. Rev. 1995, 95, 2229. (e) Amabilino, D. B.; Stoddart, J. F. Chem. Rev. 1995, 95, 2725. (f) Philp, D.; Stoddart, J. F.
Angew. Chem., Int. Ed. Engl. 1996, 35, 1154. (g) Jäger, R.; Vögtle, F. Angew. Chem., Int. Ed. Engl. 1997, 36, 930.

(h) Stang, P. J.; Olenyuk, B. Acc. Chem. Res. 1997, 30, 502.

(i) Conn, M. M.; Rebek, J. Jr. Chem. Rev. 1997, 97, 1647.

(j) Linton, B.; Hamilton, A. D. Chem. Rev. 1997, 97, 1669.

(k) Fujita, M. Chem. Soc. Rev. 1998, 27, 417. (1) Breen, T. L.; Tien, J.; Oliver, S. R. J.; Hadzie, T.; Whitesides, G. M. Science 1999, 284, 948. (m) Breault, G. A.; Hunter, C. A.; Mayers, P. C. Tetrahedron 1999, 55, 5265. (n) Lindoy, L. F.; Atkinson, I. M. Self-Assembly in Supramolecular Systems, In Monographs in Supramolecular Chemistry; Stoddart, J. F., Ed.; Royal Society of Chemistry: Cambridge, 2000. (o) Balzani, V.; Credi, A.; Raymo, F. M.; Stoddart, J. F. Angew. Chem. Int. Ed. 2000, 39, 3348. (p) Zimmerman, S. C.; Lawless, L. J. Top. Curr. Chem. 2001, 217, 95.

(11) Xiao, J.; Yang, M.; Lauher, J. W.; Fowler, F. W. Angew. Chem. Int. Ed. 2000, 39, 2132.

(12) Sarkar, A.; Okada, S.; Matsuzawa, H.; Matsuda, H.; Nakanishi, H. J. Mater. Chem. 2000, 10, 819; and references cited therein.

(13) Inter alia: (a) Ashton, P. R.; Chrystal, E. J. T.; Glink, P. T.; Menzer, S.; Schiavo, C.; Spencer, N.; Stoddart, J. F.; Tasker, P. A.; White, A. J. P.; Williams, D. J. Chem.-Eur. J. 1996, 2, 709. (b) Glink, P. T.; Schiavo, C.; Stoddart, J. F.; Williams, D. J. Chem. Commun. 1996, 1483. (c) Glink, P. T.; Stoddart, J. F. Pure Appl. Chem. 1998, 70, 419. (d) Fyfe, M. C. T.; Stoddart, J. F. Adv. Supramol. Chem. 1999, 5, 1. (e) Cantrill, S. J.; Pease, A. R.; Stoddart, J. F. J. Chem. Soc., Dalton Trans. 2000, 3715. (f) Kolchinski, A. G.; Busch, D. H.; Alcock, N. W. J. Chem. Soc., Chem. Commun. 1995, 1289. (g) Hubin, T. J.; Kolchinski, A. G.; Vance, A. L.; Busch, D. H. Adv. Supramol. Chem. 1995, 5, 237. (h) Yamaguchi, N.; Gibson, H. W. Angew. Chem. Int. Ed. 1999, 38, 143. (i) Takata, T.; Kihara, N. Rev. Heteroatom Chem. 2000, 22, 197.

(14) Cantrill, S. J.; Youn, G. J.; Stoddart, J. F.; Williams, D. J. J. Org. Chem. 2001, 66, 6857.

(15) Kinder, J. D.; Youngs, W. J. Organometallics 1996, 15, 460.

(16) Crystal data for 2: $\mathrm{C}_{48} \mathrm{H}_{38} \mathrm{O}_{8} \cdot \mathrm{C}_{4} \mathrm{H}_{8} \mathrm{O}, M_{\mathrm{r}}=814.93$, yellow block, $0.22 \times 0.31 \times 0.41 \mathrm{~mm}$, monoclinic, space group I $2 / a$, $a=31.788(4), b=8.6951(13), c=35.273(4) \AA$, $\beta=113.07(1)^{\circ}, V=8970(2) \AA^{3}, Z=8, \rho_{\text {calc }}=1.207 \mathrm{~g} \mathrm{~cm}^{-3}$, $\mathrm{Mo}_{\mathrm{K} a}$ radiation $(\lambda=0.71073 \AA), \mu=0.82 \mathrm{~cm}^{-1}$, $F(000)=3440, T=23{ }^{\circ} \mathrm{C}, 2 \theta_{\max }=23.5^{\circ}, 13240$ independent reflections scanned, 6623 independent reflections in refinement, 550 parameters, $R(F)=0.050[I$ $\sigma(I)], w R\left(F^{2}\right)=0.068$ (all data). Data were obtained on an Enraf-Nonius CAD-4 Turbo diffractometer. Structure refinement $(\mathrm{C}, \mathrm{O}$ atoms anisotropic, $\mathrm{H}$ atoms riding) was accomplished with teXsan (v. 1.7 for SGI workstations). Crystallographic data (excluding structure factors) for $\mathbf{2}$ have been deposited with the Cambridge Crystallographic Data Center as supplementary publication no. CCDC182774. 